OPEN ACCESS

Edited by:

Bikash Koli Dey,

Hongik University, South Korea

Reviewed by:

Arunava Majumder,

Lovely Professional University, India

Mijanur Rahaman Seikh, Kazi Nazrul University, India

Ali Akbar Shaikh,

University of Burdwan, India

*Correspondence:

Khalid Zaman

khalid_zaman786@yahoo.com

Specialty section:

This article was submitted to Sustainable Supply Chain

Management,

a section of the journal

Frontiers in Sustainability

Received: 02 May 2020

Accepted: 09 June 2020

Published: 25 August 2020

Citation:

Anser MK, Yousaf Z and Zaman $K$ (2020) Green Technology Acceptance

Model and Green Logistics

Operations: "To See Which Way the Wind Is Blowing". Front. Sustain. 1:3.

doi: 10.3389/frsus.2020.00003

\section{Green Technology Acceptance Model and Green Logistics Operations: "To See Which Way the Wind Is Blowing"}

\author{
Muhammad Khalid Anser ${ }^{1}$, Zahid Yousaf ${ }^{2}$ and Khalid Zaman ${ }^{3 *}$ \\ ${ }^{1}$ School of Public Administration, Xi'an University of Architecture and Technology, Xi'an, China, ${ }^{2}$ Higher Education \\ Department Khyber Pakhtunkhwa, Government College of Management Sciences, Abbottabad, Pakistan, ${ }^{3}$ Department of \\ Economics, University of Haripur, Haripur, Pakistan
}

The study provides a new insight to extend traditional technology acceptance model (TAM) in to energy-augmented TAM (EA-TAM) model in order to analyze the micro and macro perspectives of green enterprise technology to ensure eco-friendly products. The critical review would enhance analytical abilities to understand the main determinants of the TAM model at both firms' and industry perspective. The study proposed micro and macro enterprise energy-augmented TAM models and found that microenterprise EA-TAM associated with green investment decision that increases the use of renewable energy demand to improve logistics performance, export capabilities, technology advancement, resource inputs, and competitiveness. These factors would largely support to green product innovation, which is fueled by green R\&D expenditures. The green supply chain process would develop an attitude and behavioral intention toward the use of technology and green products, which ultimately would bond with green system use. The macro perspective of EA-TAM shows that green factors including green supplier selection, industrial green engineering, green procurement, green consumerism, green product recovery, and green innovation would increase green purchase decisions that convert into perceived ease of green products usage. The eco-product choice faced three compelling issues that could negatively affect the use of green products attitude and intentions, i.e., political constraints, carbon pricing, and consumer willingness-to-pay for public goods. The study concludes that the need for green policies is imperative to regulate firms and the industrial decision to go-for eco-friendly production. The use of renewable energy, carbon pricing and willingness-to-pay for public goods would be recommended for long-term sustainable development.

Keywords: green technology acceptance model, green logistics, renewable energy demand, green investment decision, green innovation, green system use

\section{AN OVERVIEW OF TECHNOLOGY ACCEPTANCE MODEL (TAM)}

Technology Acceptance Model (TAM) is basically an individual's acceptance of certain information technology and information system (Davis, 1989). The two most important factors of TAM model are: perceived usefulness - that shows the importance and subjective capabilities of individuals to use computer base applications in a way to derive maximum utility of his/her work to perform 
in an efficient manner. The perceived ease of use-it is related to how an individual feel easiness and capable to use computer base applications with quite low efforts. It was quite obvious that both the factors influenced by the number of external factors through which the end-use of the actual system could be halted for a while. The previous studies largely presented the numerous external factors that affect the use of the actual system, including social factors, cultural factors, and political factors (Davis, 1989; Ajzen, 1991; Taylor and Todd, 1995; Surendran, 2012; Dwivedi et al., 2019; Schmidthuber et al., 2020, etc.). The actual Davis-TAM model is presented in Figure 1 for ready reference.

Venkatesh and Bala (2008) presented the TAM model in the two different versions, i.e., TAM-2 and TAM-3, by introducing numerous exogenous factors of perceived usefulness (Venkatesh, 2000) and perceived ease of use (Venkatesh and Bala, 2008). The perceived usefulness introduced with four component items, i.e., individual standing (image) in a social circle by using technology, technology-related with his/her job requirement, improve quality of work, and end task outcome is satisfactory, while there are six component items for perceived ease of use, including, computer proficiency, an external control system for technology support, fear of technology use, computer playfulness, perceived enjoyment of technology use, and objective usability. TAM-2 and TAM-3 both qualify the utility maximization principle to improve the outcome of the end-user system. Figure 2 shows the Venkatesh and Bala-TAM models for ready reference.

In a similar connection, Kim et al. (2008) developed a TAM model for travelers and included mobile technology in information technology and system to perceived tourist's acceptability in terms of usefulness and ease of use, which becomes an integral part of the information acquiring about seeking tourism destinations, auto navigator, hotels location, flight reservation, and other travel information. TAM model includes technology experience and leisure trip experience in order to access an actual use of mobile technology in the pleasureseeking destination. Figure 3 shows the Kim-TAM model for ready reference.

Table 1 shows the current strikes of literature on TAM in different sectors.

\section{Contribution of the Study}

The study has a novel contribution in the existing literature for three different ways; firstly, it's focused on extensive review of past literature on green technology acceptance model that is linked with renewable energy demand. The green energy is vital for operating logistics operations that helpful to reduce carbon emissions and achieved sustainable supply chain management practices, both at firm and industry level. The previous studies extensively worked on green TAM, however, these studies are mainly limited to firm-level study, which is partially address to respond country's call for global warming to reduce the global average temperature $<2{ }^{\circ} \mathrm{C}$ (see McKinnon, 2010; Chaabane et al., 2011; Rezaee et al., 2017; Chelly et al., 2019, etc.). Secondly, the investment in energy infrastructure would enable logistics activities to increase exports capabilities, which would be helpful to develop an attitude toward the use of green products and make them green profit. The earlier studies moderately supported the stated argument, as it's fairly less emphasized on energy support prices in the industrial setting that negatively influenced logistics performance and supply chain process (see Degirmenci and Breitner, 2017; Ali et al., 2019; Hua and Wang, 2019, etc.). Finally, the carbon pricing strategy could be used to minimize negative environmental concerns that are less likely to explore in the earlier studies in sustainable supply chain process. The study suggested the need to include carbon taxes in EA-TAM that would be helpful to support GSCM practices across the globe (see Kardooni et al., 2016; Girod et al., 2017; Mejia, 2019, etc.).

\section{UNIFIED THEORY OF ACCEPTANCE OF USE OF TECHNOLOGY (UTAUT) IN SERVICES SECTOR}

San Martín and Herrero (2012) extended the unified theory of acceptance of the use of technology (UTAUT) in the services sector where technology is directly used to make hotel bookings/reservation online through company websites. Thus, the internet is the viable information technology factor that connected computer system through the world and get information about the hotel reservation, travel information, weather forecast etc. The UTAUT model encompassed four important factors that derive online purchase intention in rural tourism, i.e., (i) effort expectancy, (ii) social influence, (iii) facilitating conditions, and (iv) consumer innovativeness toward the use of new technology. Tom Dieck and Jung (2018) developed mobile augmented TAM and proposed seven external dimensions through which behavioral intention leads toward the use of technology and its application for visiting urban heritage tourism, i.e., (i) information quality, (ii) system quality, (iii) costs of use, (iv) recommendations, (v) personal innovativeness, (vi) risk, and (vii) facilitating conditions. These external factors influenced the tourist's perceptions and developed differential attitude toward use or not to use this application for visitation in pleasure destinations. Figure $\mathbf{4}$ shows Tom Dieck and Jung-TAM for ready reference.

The UTAUT model is further discussed in the domain of sustainable technology products where the emphasis is shifted from e-technology to smart and sustainable technologies. Ahn et al. (2016) extended the UTAUT model by including different external factors related to the adoption of green household technology, including, (i) performance expectancy, (ii) effort expectancy, (iii) compatibleness expectancy, (iv) hedonic expectancy, (v) social pressure, (vi) sustainable innovativeness, and (vii) environmentalism. Thus, these seven exogenous factors influenced behavioral intention to use sustainable household technology. Hsu et al. (2017) argued that green information technology products (e-books) helpful to disseminate environmental concerns that intensify the need to buy e-books to care for the natural environment, thus consumer's knowledge played an important role in UTAUT modeling to publicize environmental friendliness technology for green development. Ma et al. (2017) found that sustainable label reading behavior of the products increase the intention to use sustainable products as compared to the non-label products. 


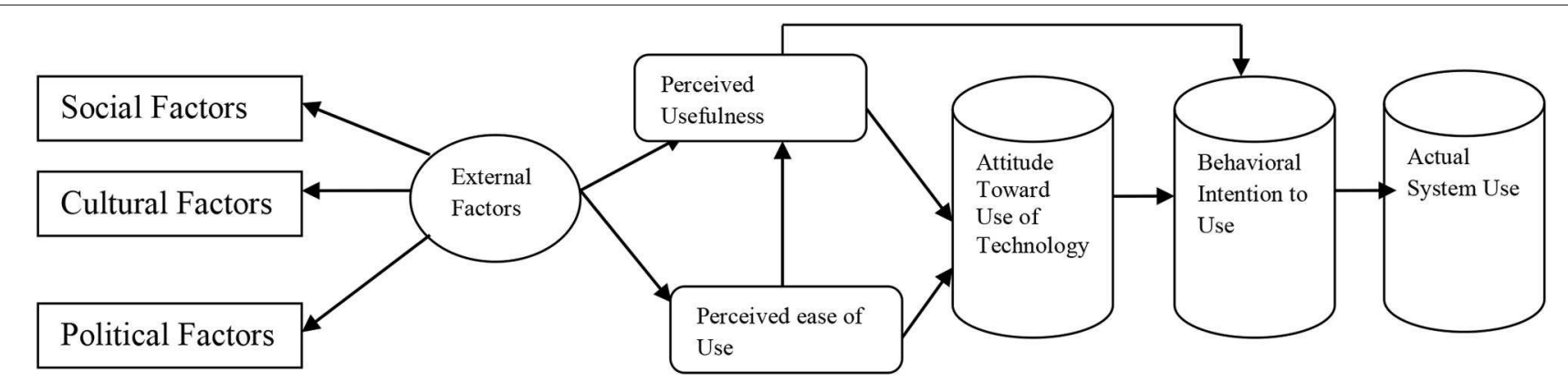

FIGURE 1 | Davis-technology acceptance model. Source: adapted from Davis (1989).

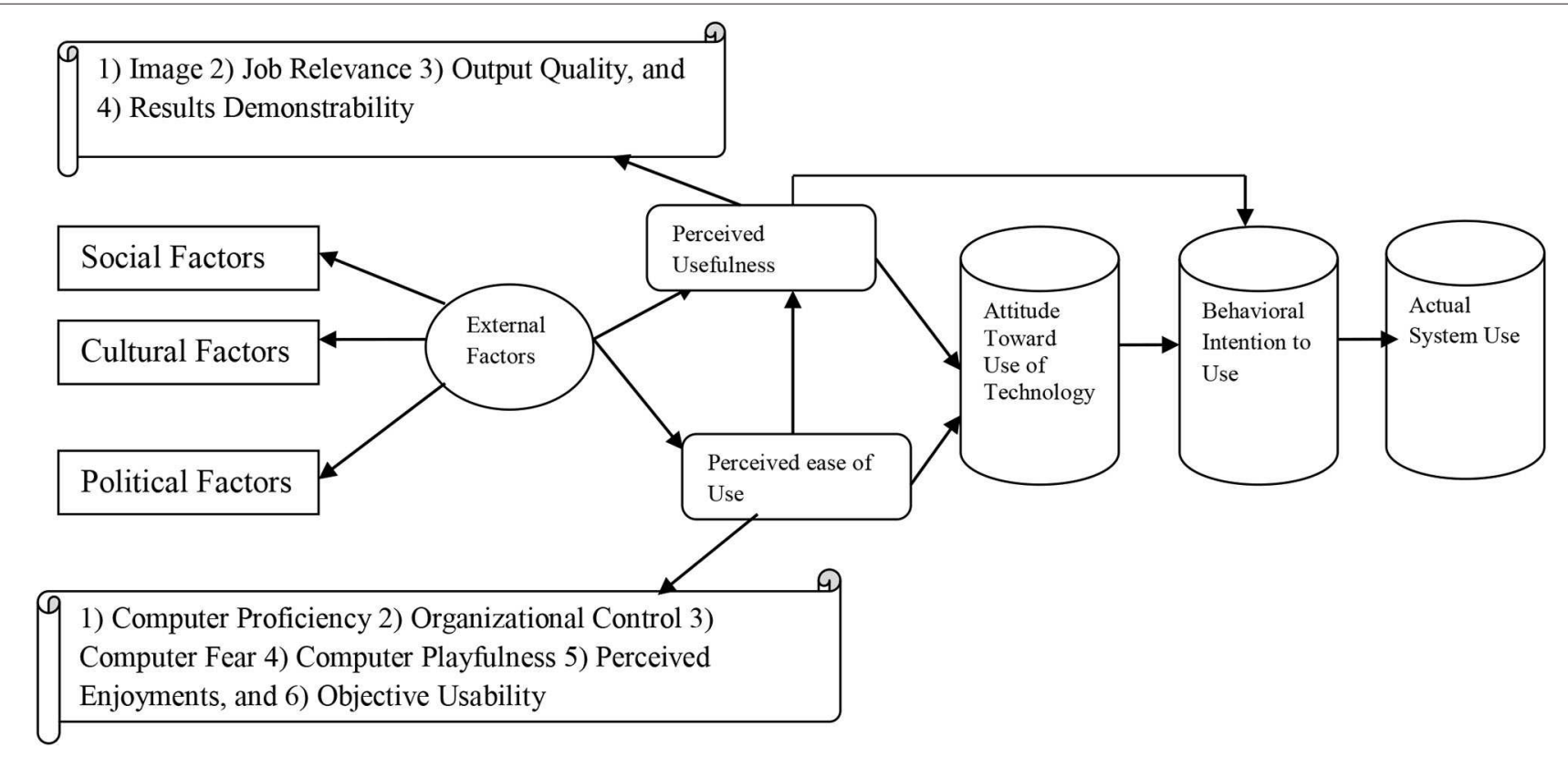

FIGURE 2 | Venkatesh and Bala-technology acceptance models. Source: adapted from Venkatesh and Bala (2008).

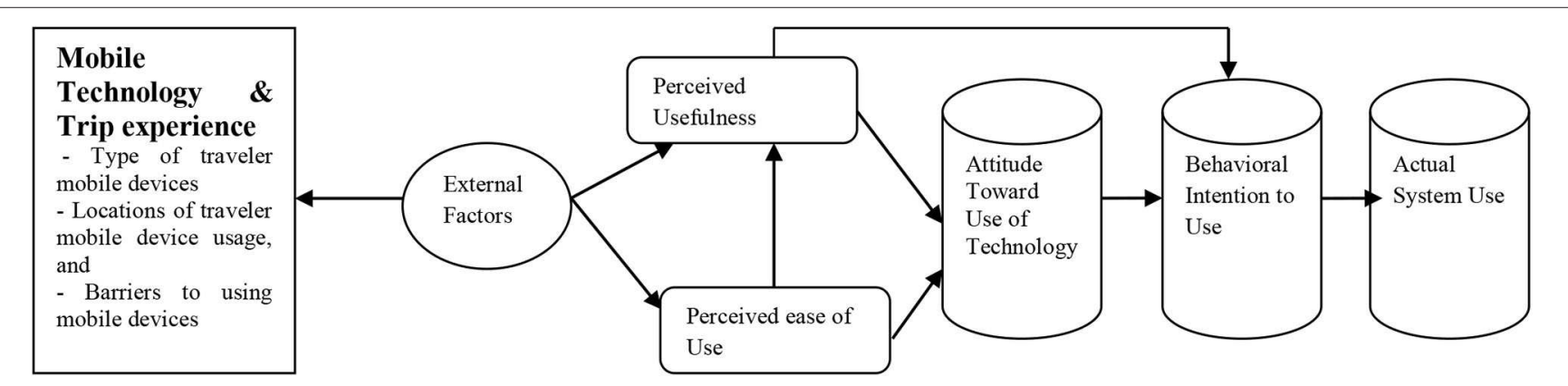

FIGURE 3 | Kim-technology acceptance model. Source: adapted from Kim et al. (2008).

Thus, the technology acceptance model is worked in the domain of environmentalism more than the non-sustainable products, which is imperative to develop a greater attitude toward using sustainable products. Figure 5 shows the green technology acceptance model for safeguarding the natural environment.

\section{ENERGY-AUGMENTED TECHNOLOGY ACCEPTANCE MODEL (EA-TAM)}

The above pictorial review gives a pearl of analytical wisdom to extend the TAM model into energy augmented TAM (EA-TAM). 
TABLE 1 | Current literature on TAM.

\begin{tabular}{|c|c|c|c|c|}
\hline References & Technology sector & Country & Participants & Results \\
\hline Islam (2020) & $\begin{array}{l}\text { Wireless internet } \\
\text { service }\end{array}$ & Malaysia & $\begin{array}{l}285 \text { university } \\
\text { students }\end{array}$ & $\begin{array}{l}\text { PEU positively influenced on student's satisfaction in using } \\
\text { wireless internet. }\end{array}$ \\
\hline Lee and Moon (2020) & $\begin{array}{l}\text { Didi Chuxing-mobile } \\
\text { technology }\end{array}$ & China & 314 users & $\begin{array}{l}\text { Service quality positively influenced to mobile technology, } \\
\text { while mobile technology leads to customer's satisfaction. }\end{array}$ \\
\hline Adepoju and Adeniji (2020) & E-banking & Nigeria & 304 users & $\begin{array}{l}\text { PU significantly increases the user intention to use E-banking } \\
\text { products. }\end{array}$ \\
\hline Vahdat et al. (2020) & $\begin{array}{l}\text { Mobile app } \\
\text { technology }\end{array}$ & Iran & 777 app users & $\begin{array}{l}\text { PEU, SPI, and ITP positively influenced on attitude toward } \\
\text { use of mobile apps. }\end{array}$ \\
\hline Rafique et al. (2020) & $\begin{array}{l}\text { TAM library } \\
\text { applications }\end{array}$ & Pakistan & 340 MLA users & PU and PEU both are the strong predictors of the use of MLA. \\
\hline Kamal et al. (2020) & $\begin{array}{l}\text { Telemedicine } \\
\text { services }\end{array}$ & Pakistan & 275 users & $\begin{array}{l}\text { The intention to acquire telemedicine services influenced with } \\
\text { PEU, SPI, PR, trust, and technology resistance. }\end{array}$ \\
\hline Faustino and Simões (2020) & $\begin{array}{l}\text { Technology based } \\
\text { teaching and } \\
\text { learning process }\end{array}$ & Bibliometric analysis & $\begin{array}{l}\text { Last } 10 \text { years } \\
\text { studies }\end{array}$ & $\begin{array}{l}\text { The Bibliometric analysis shows that TAM is largely discussed } \\
\text { as for student point of view while less talk about for teachers' } \\
\text { point of view. Further PU, PEU, and self-efficacy are the main } \\
\text { factors of technology acceptance. }\end{array}$ \\
\hline Elshafey et al. (2020) & $\begin{array}{l}\text { Construction } \\
\text { industry }\end{array}$ & $\begin{array}{l}4 \text { developing } \\
\text { countries }\end{array}$ & 58 respondents & $\begin{array}{l}\text { The users control over building information and augmented } \\
\text { reality, and PEU has the greater influence on actual system } \\
\text { use that positively affects their intention to use the system. }\end{array}$ \\
\hline Winarno and Putra (2020) & $\begin{array}{l}\text { Financial reporting } \\
\text { system }\end{array}$ & Indonesia & 73 respondents & PEU positively influenced with respondents' experiences. \\
\hline Sohn and Kwon (2020) & Artificial intelligence & Korea & 378 respondents & $\begin{array}{l}\text { PEU, enjoyment, and technical ability largely increase } \\
\text { perceived value. }\end{array}$ \\
\hline Rezaei et al. (2020) & $\begin{array}{l}\text { Ecological } \\
\text { conservation }\end{array}$ & Iran & 327 farmers & $\begin{array}{l}\text { The intention to use integrated pest management in tomato } \\
\text { growers largely explained by farmers' attitude, PU, and PEU } \\
\text { that shows the ecological concerns of the farmers in } \\
\text { application of pest management. }\end{array}$ \\
\hline Mousa et al. (2020) & E-learning & Iraq & 450 students & $\begin{array}{l}\text { PU and PEU both are the potential factor that positively } \\
\text { influenced to students' intention to use E-learning. }\end{array}$ \\
\hline Ardiansah et al. (2020) & E-commerce & Indonesia & 96 users & E-commerce applications influenced by PEU. \\
\hline
\end{tabular}

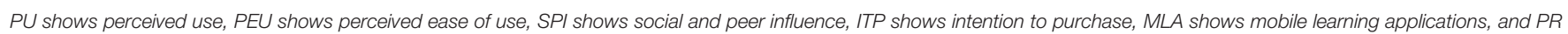
shows perceived risk.

The EA-TAM model shows that technology always remains required more energy in order to perform its functioning ability to gear business activities. Thus, the need for energy demand always plays a pivotal role in economic activity that would be helpful to achieve green development agenda. The technology embodied emissions largely released during the production process, thus the need for green energy is always required for moving toward sustainable development. The role of renewable energy sources in technology-oriented growth is imperative for low emissions growth. Thus, on the basis of the significance of the debate, the study proposed EA-TAM model both in micro and macro perspectives. Figure 6 shows the EA-TAM Model in micro-perspectives (firms view).

Figure $\mathbf{6}$ shows the firm's view of energy-augmented TAM model and argued that renewable energy is deemed desirable in order to proceed toward green investment decision, which improves logistics performance, exports capabilities, technology advancement, resource inputs, improves competitiveness, and increase firms' payoff. The green energy demand is further helpful to get product innovations, which need high R\&D expenditures in order to develop a green attitude and behavioral intention to use green system use. The firm's view of EA-TAM provides a pragmatic approach that would help to devise firms' green policies to get green payoffs. Figure 7 shows the macro perspective of EA-TAM model (industry view).

Figure 7 shows the industry view of EA-TAM and argued that green factors played an important role in green product usage, as green supplier selection would be helpful to make a green purchase intentions, while industrial green engineering, green procurement, green consumerism, green product recovery, and green innovation would be helpful to increase the perceived ease of green product use. There would be a lot of factors that could be cumbersome the process of green innovation including political constraints and high carbon price, which ultimately affect green attitude preferences to use green products. Finally, green preferences would extend eco-product choice that led to increase green product usage. Table 2 summarized the results of the stated study with the earlier studies for ready reference.

On the basis of significant discussion on the stated topic, it is clear that the subject matter is highly important in order to make EA-TAM proceed for GSCM practices both at micro and macro level. The EA-TAM is different from other green TAM in the literature on the basis of five important distinctions, i.e.,

(i) Green investment in the energy sector makes them logistic operations greener. 


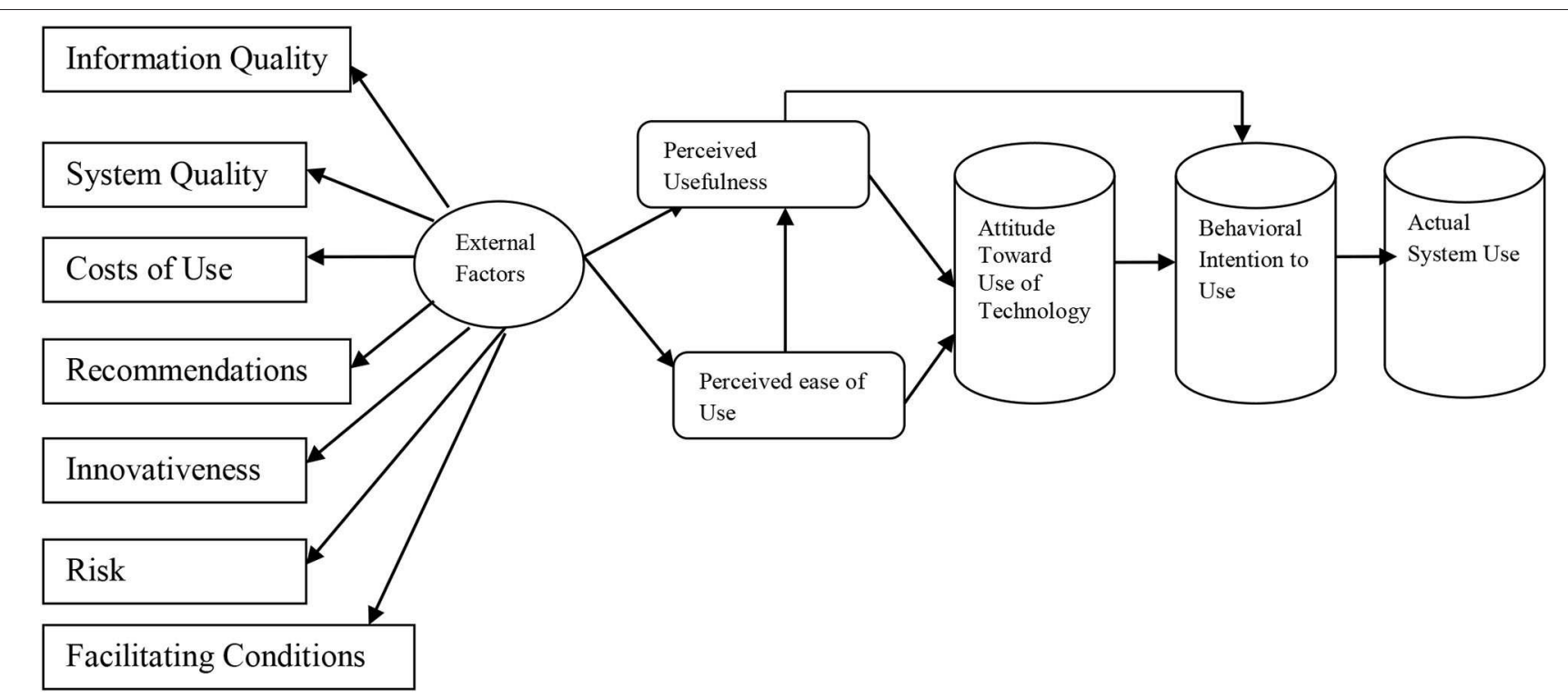

FIGURE 4 | Tom Dieck and Jung-technology acceptance model. Source: adapted from Tom Dieck and Jung (2018).

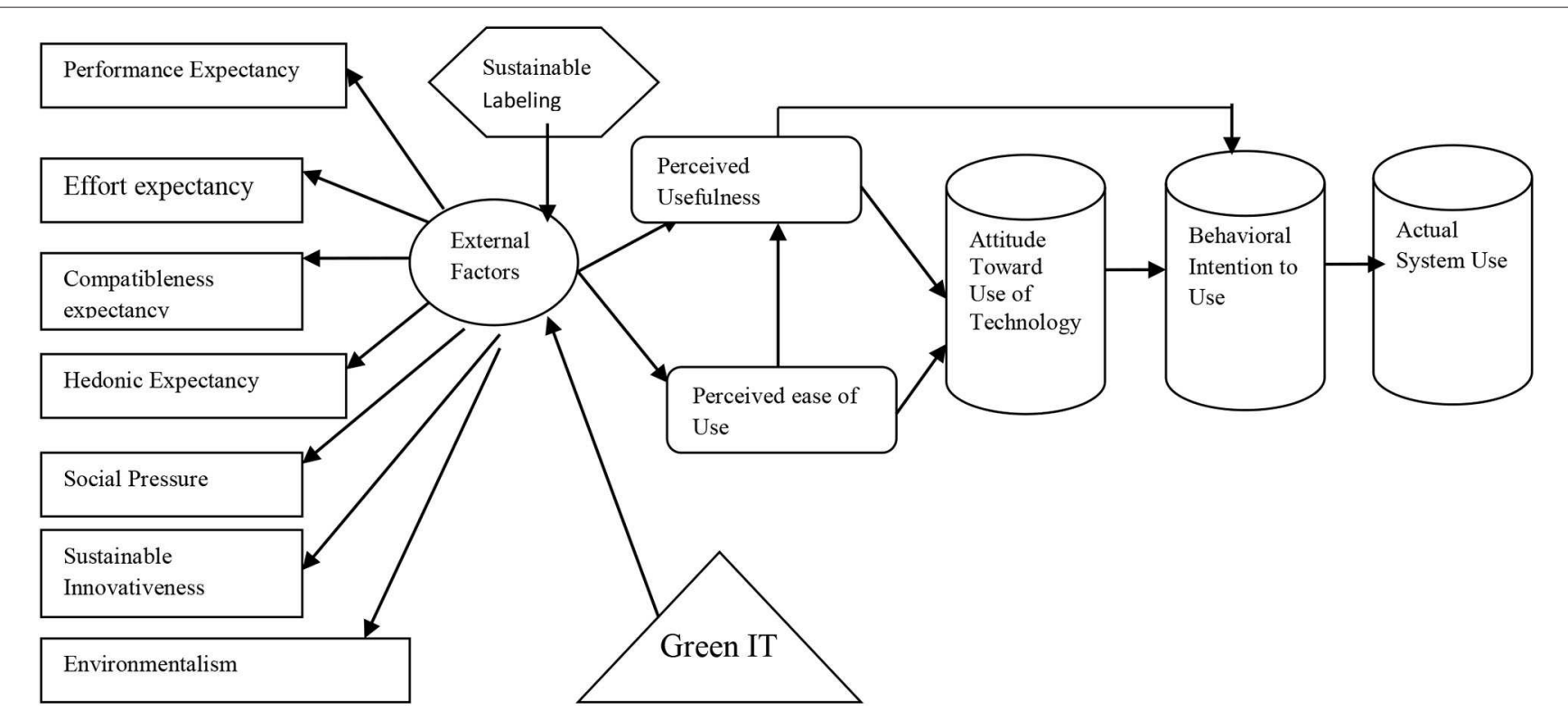

FIGURE 5 | Green TAM-environmentalism, green information technology, and sustainable products labeling. Source: adapted from Ahn et al. (2016), Ma et al. (2017), and Hsu et al. (2017).

(ii) Technology advancement in cleaner production could be achieved through the inclusion of renewable energy demand in existing energy portfolios.

(iii) Exports competitiveness and energy support prices developed an attitude toward the use of green products.

(iv) The eco-friendly products usage is the subject matter of carbon pricing, and

(v) Political disinclination makes it difficult to achieve GSCM practices that could be inclined through the development of green protocols.
The view of green TAM model gives greater insights in order to extend conventional TAM model in to energy-augmented TAM model, which would be helpful to the firm's and industry to gofor-green policies. The logistics operation can be benefited by EA-TAM in a variety of ways, which is not limited to the following factors, i.e.,

(i) Substantial reduction in energy costs in logistics operations can be achieved through energy efficiency.

(ii) Vehicles fuel intensity can be increased by subsidizing renewable fuel prices, efficient carbon taxes, provision 

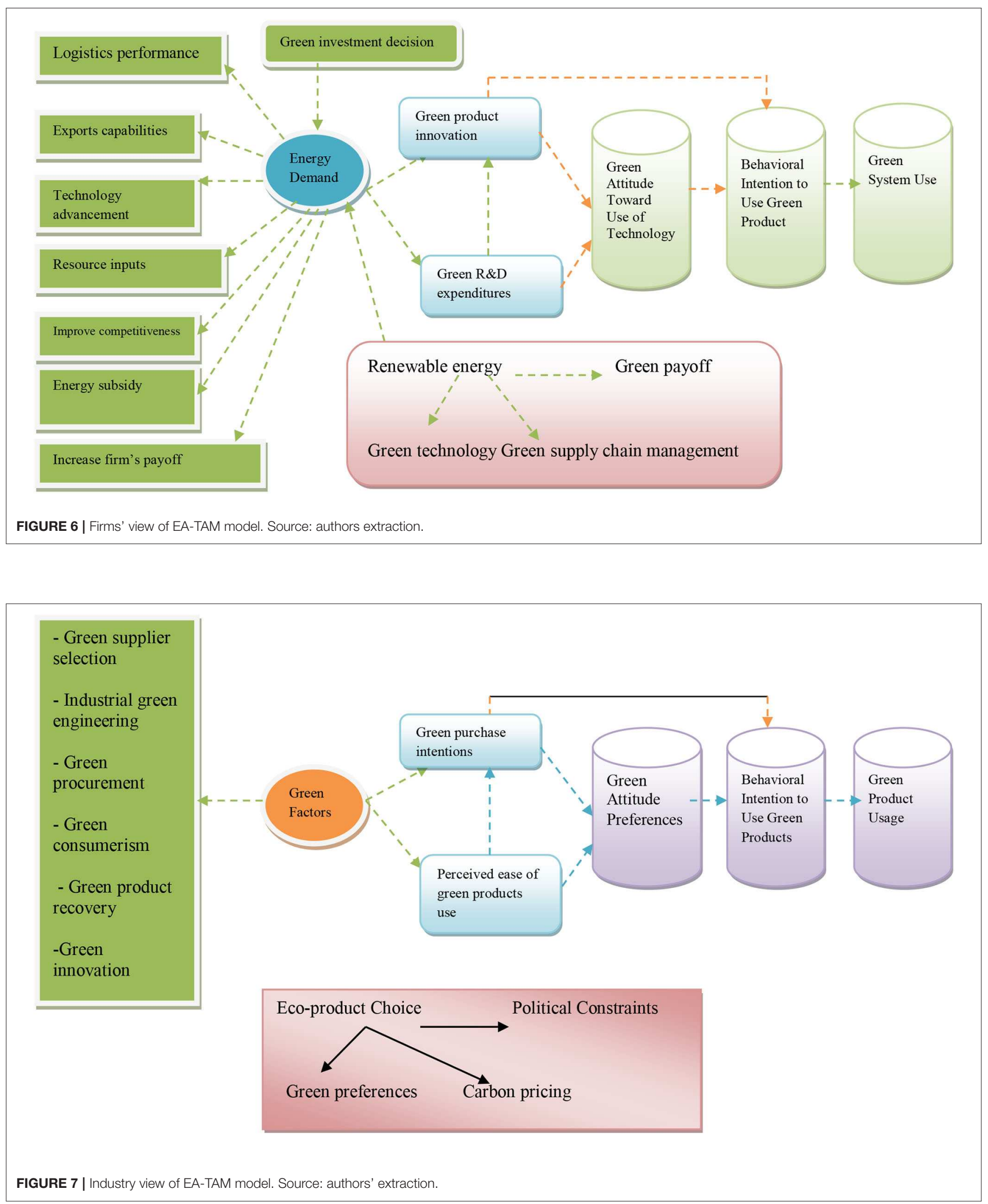
TABLE 2 | Summarized the current work with the existing work.

\begin{tabular}{|c|c|c|}
\hline Factors & Current work & Existing work \\
\hline Novelty & $\begin{array}{l}\text { The novel contribution of the study is to extend the original } \\
\text { TAM model into energy-augmented TAM both at micro and } \\
\text { macro perspectives. }\end{array}$ & $\begin{array}{l}\text { The exiting literature are majorly worked on the services sector and } \\
\text { developed a TAM model for micro perspectives (see Kamel and } \\
\text { Hassan, 2006; Sang and Lee, 2009; Lee and Song, 2013; } \\
\text { Memarzadeh and Anand, 2020; Schmidthuber et al., 2020, etc.), } \\
\text { while little work has been done on macroeconomic perspectives that } \\
\text { is fairly needed for sound policy implications. }\end{array}$ \\
\hline $\begin{array}{l}\text { Green logistics } \\
\text { operations }\end{array}$ & $\begin{array}{l}\text { The study largely emphasized the need to adopt green } \\
\text { logistics operations as it is the major component of the supply } \\
\text { chain management process. The study highlighted different } \\
\text { socio-economic and environmental factors that are attached } \\
\text { to renewable demand, green RandD, and carbon pricing. }\end{array}$ & $\begin{array}{l}\text { The existing literature is limited to sustainable innovation and exports } \\
\text { competitiveness while it largely lacks carbon pricing instruments, } \\
\text { including a carbon tax and emissions-cap modeling, which is } \\
\text { deemed desirable to replace fossil fuel combustion with renewable } \\
\text { fuels in logistics operations (see Akman and Mishra, 2015; Chen and } \\
\text { Lu, 2016; lbrahim et al., 2019; Zhang et al., 2020, etc.). }\end{array}$ \\
\hline $\begin{array}{l}\text { Advancement in the } \\
\text { cleaner production }\end{array}$ & $\begin{array}{l}\text { The current study largely stresses the need to use cleaner } \\
\text { production technologies that support to reduce industrial } \\
\text { waste and improves a firm's competitiveness. }\end{array}$ & $\begin{array}{l}\text { The few existing studies used micro data to support the given } \\
\text { argument, while at a macro level; there is no direct study available to } \\
\text { comprehend the statement (see lbrahim et al., 2017; Biswas and } \\
\text { Roy, 2018; Sheen, 2018; Samad et al., 2020, etc.). }\end{array}$ \\
\hline $\begin{array}{l}\text { Eco-products } \\
\text { choice }\end{array}$ & $\begin{array}{l}\text { The study accentuates to stabilize political constraints for } \\
\text { eco-products choice, as it is mixed with green preferences } \\
\text { and carbon pricing. }\end{array}$ & $\begin{array}{l}\text { The existing studies largely discussed eco-products choice through } \\
\text { consumer's green preferences while its largely ignored carbon pricing } \\
\text { mechanism and political constraints altogether that needed to } \\
\text { perform GSCM practices (see Arce Salazar and Oerlemans, 2016; } \\
\text { Chuang and Liao, 2018; Qu et al., 2020, etc.). }\end{array}$ \\
\hline $\begin{array}{l}\text { GSCM practices } \\
\text { and country's } \\
\text { economic growth }\end{array}$ & $\begin{array}{l}\text { The study heightens the need to adopt GSCM practices in } \\
\text { order to support a country's economic growth under EA-TAM } \\
\text { modeling, as renewable energy demand is the optimized } \\
\text { solution to reduce negative environmental externalities and } \\
\text { support to green economic development. }\end{array}$ & $\begin{array}{l}\text { The earlier studies generally explored differently firm's level } \\
\text { determinants of GSCM practices, while it's less explored the viability } \\
\text { of renewable energy demand in economic sectors to supports the } \\
\text { country's economic growth (see Rajabian Tabesh et al., 2016; } \\
\text { Suryanto et al., 2018; Gardas et al., 2019, etc.). }\end{array}$ \\
\hline
\end{tabular}

of energy fuel subsidy, and vehicle modification through technology upgradation.

(iii) Environmental regulatory measures would allow transporting competitive goods that helpful to mitigate GHG emissions.

(iv) Private investment in green energy infrastructure would be helpful to increase sustainable transportation network and

(v) Clean energy shifts make them shift the logistics business toward green logistics.

The use of renewable energy not only limited to increase exports competency, innovation, and green payoff while it increases green investment decisions to raise green preferences to use eco-friendly goods through green logistics operations.

\section{MANAGERIAL IMPLICATIONS AND INDUSTRIAL BENEFITS}

The greater viability in the EA-TAM in logistics operations tend to support corporate profit in a variety of ways, as supply chain managers should require more policy-oriented and strategic wisdom in order to develop corporate environmental policies that make them competitive enough to retain green profit. Eco-design practices are largely lagging behind the success of GSCM practices, managers should be well-versed with technical, regulatory, and environmentally sound to minimize environmental concerns in disposing of manufacturing products. The imposition of carbon taxes on dirty production is imperative to sustained long-term growth, while this also hold for logistics operations that largely worked in tracking consignments, customs clearance, and delivered products in the stipulated time period. All these activities required more energy to perform their functions efficiently, which leads to environmental degradation. The high dependency on fossil fuel energy leaves many unanswered about product efficiency and corporate policies. The managers should have to develop green corporate policies to replace fossil fuel to rentable fuels in logistics operations and get a competitive advantage on other firms to make a new product line as per see corporate environmental policies.

\section{CONCLUSIONS}

The study has a novel contribution in the earlier studies into three different perspectives; firstly, the study proposed micro-enterprise energy-augmented TAM that is associated with the adoption of green technology that leads to go-for-green product innovation. The green investment decision developed an attitude and intention to use a green product, which increases firms' payoffs. Secondly, the study proposed macro enterprise energy-augmented TAM that is linked with the following green factors including green supplier selection, green engineering, procurement, consumerism, product recovery, and green innovation. These stated factors lead to green purchase intentions and ease of green products use that developed an attitude and intention to use eco-friendly products. Finally, the study introduced three compelling factors that could negatively 
affect the green product use, including political constraints, carbon pricing, and willingness-to-pay for public goods. The study presented these factors in a simple and pragmatic approach via a pictorial review that increases an analytical ability to understand common problems of enterprise technology adoption both at micro and macro perspectives. The use of renewable energy demand in the TAM model gives more wisdom to devise sustainable development policies on a global scale. The following policy implications have been proposed in a given scenario, i.e.,

(i) The enterprise TAM should be fueled with green R\&D expenditures in the energy sector to reduce negative environmental externalities that take place during the production process.

(ii) The implementation of carbon pricing on dirty polluting industries would be highly desirable in order to get fruits from the use of green products.

(iii) The political constraints should be resolved in the adoption of renewable energy in the conventional energy mix, which would help to subsidize the energy market and lowering energy price.

(iv) Green purchase intention is linked with green product innovation, thus both factors should be under consideration while devising green policies, and

(v) The green investment decision is important both at the firm and industrial perspective that would be helpful to reduce environmental externalities and improve competitiveness

\section{REFERENCES}

Adepoju, A., and Adeniji, A. (2020). Technology acceptance of e-banking services in an unnatural environment. SEISENSE J. Manage. 3, 34-50. doi: 10.33215/sjom.v3i3.336

Ahn, M., Kang, J., and Hustvedt, G. (2016). A model of sustainable household technology acceptance. Int J Consum Stud. 40, 83-91. doi: 10.1111/ijcs.12217

Ajzen, I. (1991). The theory of planned behaviour. Organ. Behav. Hum. Decis. Process 50, 179-211. doi: 10.1016/0749-5978(91)90020-T

Akman, I., and Mishra, A. (2015). Sector diversity in green information technology practices: technology acceptance model perspective. Comput. Hum. Behav. 49, 477-486. doi: 10.1016/j.chb.2015.03.009

Ali, S., Ullah, H., Akbar, M., Akhtar, W., and Zahid, H. (2019). Determinants of consumer intentions to purchase energy-saving household products in Pakistan. Sustainability 11:1462. doi: 10.3390/su11051462

Arce Salazar, H., and Oerlemans, L. (2016). Do we follow the leader or the masses? Antecedents of the willingness to pay extra for eco-products. J. Consum. Aff. 50, 286-314. doi: 10.1111/joca.12074

Ardiansah, M., Chariri, A., Rahardja, S., and Udin, U. (2020). The effect of electronic payments security on e-commerce consumer perception: an extended model of technology acceptance. Manage. Sci. Lett. 10, 1473-1480. doi: $10.5267 /$ j.msl.2019.12.020

Biswas, A., and Roy, M. (2018). Technology acceptance perception for promotion of sustainable consumption. Environ. Sci. Pollut. Res. 25, 6329-6339. doi: 10.1007/s11356-017-0964-4

Chaabane, A., Ramudhin, A., and Paquet, M. (2011). Designing supply chains with sustainability considerations. Prod. Plan. Control 22, 727-741. doi: 10.1080/09537287.2010.543554

Chelly, A., Nouira, I., Frein, Y., and Hadj-Alouane, A. B. (2019). On the consideration of carbon emissions in modelling-based supply chain literature: the state of the art, relevant features and research gaps. Int. J. Prod. Res. 57, 4977-5004. doi: 10.1080/00207543.2018.1497310 and exports capabilities to get involved customers in green system use.

\section{Limitations and Future Extension of the Study}

The study is limited to critical reviews of past studies on green logistics policies within the sustainable supply chain management across the globe. The empirical data both at the micro and macro level would be helpful to explore the green determinants of sustainable supply chain management. This study is exploratory in nature and at an initial stage, there is deemed desirable to proposed GSCM model, while at the later stages, the empirical extension of the study would be further added for robust inferences. The future work has been planned to test the given theoretical models by mix methods approach wide across the globe. The proposed model is based upon pragmatic approach and it is well-linked with the exiting studies, thus on the basis of significant discussion, the empirical model would be attractive enough to open new avenues of the future work on the stated theme.

\section{AUTHOR CONTRIBUTIONS}

MA: supervision, writing-reviewing and editing, conceptualization, methodology, and supervision. ZY: software and formal analysis. KZ: data curation and validation. All authors contributed to the article and approved the submitted version.

Chen, S. Y., and Lu, C. C. (2016). Exploring the relationships of green perceived value, the diffusion of innovations, and the technology acceptance model of green transportation. Transp. J. 55, 51-77. doi: 10.5325/transportationj.55.1.0051

Chuang, H. K., and Liao, C. S. (2018). Consumer preferences for green digital camera attributes to inform electrical and electronic equipment design and development. J. Environ. Plan. Manage. 61, 2186-2206. doi: 10.1080/09640568.2017.1389700

Davis, F. D. (1989). Perceived usefulness, perceived ease of use, and user acceptance of information technology. MIS Q. 13, 319-340. doi: 10.2307/249008

Degirmenci, K., and Breitner, M. H. (2017). Consumer purchase intentions for electric vehicles: is green more important than price and range? Transp. Res. D Transp. Environ. 51, 250-260. doi: 10.1016/j.trd.2017.01.001

Dwivedi, Y. K., Rana, N. P., Jeyaraj, A., Clement, M., and Williams, M. D. (2019). Re-examining the unified theory of acceptance and use of technology (UTAUT): towards a revised theoretical model. Inf. Syst. Front. 21, 719-734. doi: 10.1007/s10796-017-9774-y

Elshafey, A., Saar, C. C., Aminudin, E. B., Gheisari, M., and Usmani, A. (2020). Technology acceptance model for Augmented Reality and Building Information Modeling integration in the construction industry. J. Inf. Technol. Constr. 25, 161-172. doi: 10.36680/j.itcon.2020.010

Faustino, P., and Simões, D. (2020). "The contribution of the technology acceptance model for an active teaching and learning process in higher education: a bibliometric analysis," in Handbook of Research on Digital Learning, ed M. Montebello (Hershey, PA: IGI Global), 242-261. doi: 10.4018/978-1-5225-9304-1.ch015

Gardas, B. B., Raut, R. D., and Narkhede, B. (2019). Determinants of sustainable supply chain management: a case study from the oil and gas supply chain. Sustain. Prod. Consum. 17, 241-253. doi: 10.1016/j.spc.2018.11.005

Girod, B., Mayer, S., and Nägele, F. (2017). Economic versus belief-based models: shedding light on the adoption of novel green technologies. Energy Policy 101, 415-426. doi: 10.1016/j.enpol.2016.09.065 
Hsu, C. L., Chen, M. C., and Lin, Y. H. (2017). Information technology adoption for sustainable development: green e-books as an example. Inf. Technol. Dev. 23, 261-280. doi: 10.1080/02681102.2017.1298078

Hua, L., and Wang, S. (2019). Antecedents of consumers' intention to purchase energy-efficient appliances: an empirical study based on the technology acceptance model and theory of planned behavior. Sustainability 11:2994. doi: $10.3390 /$ sul1102994

Ibrahim, I., Sundram, V. P. K., Omar, E. N., Yusoff, N., and Amer, A. (2019). The determinant factors of green practices adoption for logistics companies in Malaysia. A case study of PKT Logistics Group Sdn. Bhd. J. Emerg. Econ. Islam. Res. 7, 14-23. doi: 10.24191/jeeir.v7i1.6023

Ibrahim, R., Leng, N. S., Yusoff, R. C. M., Samy, G. N., Masrom, S., and Rizman, Z. I. (2017). E-learning acceptance based on technology acceptance model (TAM). J. Fundam. Appl. Sci. 9, 871-889. doi: 10.4314/jfas.v9i4S.50

Islam, A. Y. M. A. (2020). Viability of the extended technology acceptance model: an empirical study. J. Inform. Commun. Technol. 10, 85-98.

Kamal, S. A., Shafiq, M., and Kakria, P. (2020). Investigating acceptance of telemedicine services through an extended technology acceptance model (TAM). Technol. Soc. 60:101212. doi: 10.1016/j.techsoc.2019.10 1212

Kamel, S., and Hassan, A. (2006). "Assessing the introduction of electronic banking in Egypt using the technology acceptance model," in Cases on Electronic Commerce Technologies and Applications, ed D. B. A. Mehdi Khosrow-Pour (Hershey, PA: IGI Global), 296-320. doi: 10.4018/978-1-59904-402-6.ch018

Kardooni, R., Yusoff, S. B., and Kari, F. B. (2016). Renewable energy technology acceptance in Peninsular Malaysia. Energy Policy 88, 1-10. doi: 10.1016/j.enpol.2015.10.005

Kim, D. Y., Park, J., and Morrison, A. M. (2008). A model of traveller acceptance of mobile technology. Int. J. Tour. Res. 10, 393-407. doi: 10.1002/jtr.669

Lee, J. H., and Song, C. H. (2013). Effects of trust and perceived risk on user acceptance of a new technology service. Soc. Behav. Pers. 41, 587-597. doi: 10.2224/sbp.2013.41.4.587

Lee, E. J., and Moon, J. Y. (2020). A study on effects of service quality and technology acceptance model in China-the moderate effect on reliability. J. Korea Soc. Comput. Inf. 25, 97-107. doi: 10.9708/jksci.2020.25.03.097

Ma, Y. J., Gam, H. J., and Banning, J. (2017). Perceived ease of use and usefulness of sustainability labels on apparel products: application of the technology acceptance model. Fash. Text. 4:3. doi: 10.1186/s40691-017-0093-1

McKinnon, A. (2010). Green logistics: the carbon agenda. Electron. Sci. J. Logist. $6,1-9$.

Mejia, C. (2019). Influencing green technology use behavior in the hospitality industry and the role of the "green champion". J. Hosp. Mark. Manage. 28, 538-557. doi: 10.1080/19368623.2019.1539935

Memarzadeh, F., and Anand, S. (2020). Hotel guests' perceptions of green technology applications, and practices in the hotel industry. Int. J. Tour. Hosp. Manage. Digit. Age 4, 1-9. doi: 10.4018/IJTHMDA.2020010101

Mousa, A. H., Mousa, S. H., Mousa, S. H., and Obaid, H. A. (2020). "Advance acceptance status model for e-learning based on university academics and students," in IOP Conference Series: Materials Science and Engineering, Vol. 671 (Bristol: IOP Publishing), 012031. doi: 10.1088/1757-899X/671/1/012031

Qu, G., Zhang, Z., Qu, W., and Xu, Z. (2020). Green supplier selection based on green practices evaluated using fuzzy approaches of TOPSIS and ELECTRE with a case study in a Chinese internet company. Int. J. Environ. Res. Public Health 17:3268. doi: 10.3390/ijerph17093268

Rafique, H., Almagrabi, A. O., Shamim, A., Anwar, F., and Bashir, A. K. (2020). Investigating the acceptance of mobile library applications with an extended technology acceptance model (TAM). Comput. Educ. 145:103732. doi: 10.1016/j.compedu.2019.103732

Rajabian Tabesh, A., Batt, P. J., and Butler, B. (2016). Modelling the impact of environmental and organizational determinants on green supply chain innovation and performance. J. Food Prod. Mark. 22, 436-454. doi: 10.1080/10454446.2014.949987

Rezaee, A., Dehghanian, F., Fahimnia, B., and Beamon, B. (2017). Green supply chain network design with stochastic demand and carbon price. Ann. Oper. Res. 250, 463-485. doi: 10.1007/s10479-015-1936-z
Rezaei, R., Safa, L., and Ganjkhanloo, M. M. (2020). Understanding farmers' ecological conservation behavior regarding the use of integrated pest management-an application of the technology acceptance model. Glob. Ecol. Conserv. 22:e00941. doi: 10.1016/j.gecco.2020.e00941

Samad, S., Asadi, S., Nilashi, M., Ibrahim, O., Abumalloh, R. A., and Abdullah, R. (2020). Organizational performance and adoption of green IT from the lens of resource based view. J. Soft Comput. Decis. Support Syst. 7, 1-6.

San Martín, H., and Herrero, Á. (2012). Influence of the user's psychological factors on the online purchase intention in rural tourism: integrating innovativeness to the UTAUT framework. Tour. Manage. 33, 341-350. doi: $10.1016 /$ j.tourman.2011.04.003

Sang, S., and Lee, J. D. (2009). "A conceptual model of e-government acceptance in public sector," in 2009 Third International Conference on Digital Society (Cancun: IEEE), 71-76. doi: 10.1109/ICDS.2009.30

Schmidthuber, L., Maresch, D., and Ginner, M. (2020). Disruptive technologies and abundance in the service sector-toward a refined technology acceptance model. Technol. Forecast. Soc. Change 155:119328. doi: 10.1016/j.techfore.2018. 06.017

Sheen, A. Jr. (2018). Determining relationships between technology acceptance and refinery worker attitudes towards renewable energy technology at the Limetree Bay facility on St. (Doctoral dissertation). Northcentral University, Croix, US VirginIslands, United States.

Sohn, K., and Kwon, O. (2020). Technology acceptance theories and factors influencing artificial intelligence-based intelligent products. Telemat. Inform. 47:101324. doi: 10.1016/j.tele.2019.101324

Surendran, P. (2012). Technology acceptance model: a survey of literature. Int. J. Bus. Soc. Res. 2, 175-178. doi: 10.18533/ijbsr.v2i4.161

Suryanto, T., Haseeb, M., and Hartani, N. H. (2018). The correlates of developing green supply chain management practices: firms level analysis in Malaysia. Int. J. Supply Chain Manage. 7, 316-324.

Taylor, S., and Todd, P. A. (1995). Understanding information technology usage: a test of competing models. Inf. Syst. Res. 6, 144-176. doi: 10.1287/isre.6.2.144

Tom Dieck, M. C., and Jung, T. (2018). A theoretical model of mobile augmented reality acceptance in urban heritage tourism. Curr. Iss. Tour. 21, 154-174. doi: $10.1080 / 13683500.2015 .1070801$

Vahdat, A., Alizadeh, A., Quach, S., and Hamelin, N. (2020). Would you like to shop via mobile app technology? The technology acceptance model, social factors and purchase intention. Australas. Mark. J. doi: 10.1016/j.ausmj.2020.01.002. [Epub ahead of print].

Venkatesh, V. (2000). Determinants of perceived ease of use: integrating control, intrinsic motivation, and emotion into the technology acceptance model. Inf. Syst. Res. 11, 342-365. doi: 10.1287/isre.11.4.342.11872

Venkatesh, V., and Bala, H. (2008). Technology acceptance model 3 and a research agenda on interventions. Decis. Sci. 39, 273-315. doi: $10.1111 / j .1540-5915.2008 .00192 . x$

Winarno, W. A., and Putra, H. S. (2020). Technology acceptance model of the Indonesian government financial reporting information systems. Int. J. Public Sect. Perform. Manage. 6, 68-84. doi: 10.1504/IJPSPM.2020. 105089

Zhang, W., Zhang, M., Zhang, W., Zhou, Q., and Zhang, X. (2020). What influences the effectiveness of green logistics policies? A grounded theory analysis. Sci. Total Environ. 714:136731. doi: 10.1016/j.scitotenv.2020. 136731

Conflict of Interest: The authors declare that the research was conducted in the absence of any commercial or financial relationships that could be construed as a potential conflict of interest.

Copyright (c) 2020 Anser, Yousaf and Zaman. This is an open-access article distributed under the terms of the Creative Commons Attribution License (CC BY). The use, distribution or reproduction in other forums is permitted, provided the original author(s) and the copyright owner(s) are credited and that the original publication in this journal is cited, in accordance with accepted academic practice. No use, distribution or reproduction is permitted which does not comply with these terms. 